Article

\title{
Impacts of Socio-Psychological Factors on Actual Adoption of Sustainable Land Management Practices in Dryland and Water Stressed Areas
}

\author{
Woldegebrial Zeweld $^{1,2, *(\mathbb{1})}$, Guido Van Huylenbroeck ${ }^{2}$ (D), Girmay Tesfay ${ }^{1}$, Hossein Azadi ${ }^{3}$ (1) \\ and Stijn Speelman ${ }^{2}$ \\ 1 Department of Agricultural and Resource Economics, Mekelle University, Mekelle P. O. Box 231, Ethiopia; \\ girmay_tesfay@yahoo.com \\ 2 Department of Agricultural Economics, Ghent University, Coupure Links 653, B-9000 Gent, Belgium; \\ guido.vanhuylenbroeck@ugent.be (G.V.H.); stijn.speelman@ugent.be (S.S.) \\ 3 Department of Geography, Ghent University, Krijgslaan 281, S8m, B-9000 Gent, Belgium; \\ hossein.azadi@ugent.be \\ * Correspondence: woldegebrial.zeweld@gmail.com; Tel.: +251-914-729526
}

Received: 22 July 2018; Accepted: 17 August 2018; Published: 21 August 2018

\begin{abstract}
Despite the presence of several studies on technology adoption, there are limited empirical studies on how socio-psychological factors affect the adoption of sustainable agriculture. Therefore, this paper investigates how socio-psychological factors-such as social capital, information, attitudes, efficacy, and aversion-affect smallholder farmers' decisions to adopt sustainable land management practices, such as agroforestry systems, organic compost, and crop rotation with legumes. Cross-sectional data are collected from 350 randomly selected farm households using a pre-tested and structured questionnaire. A multivariate probit model is used to investigate factors that influence the probability of adopting these practices. The ordered probit model is also applied to identify and analyze the determinants of the number (intensity) of land management practices adopted. The findings indicate that nearly half of the farmers have adopted these land management practices to improve soil fertility, enhance water retention capacity, and increase productivity. It is also found that attitudes, information, education, group membership, relational capital, risk attitudes, and labor supply significantly affect the probability of adopting these agricultural practices. The estimates of the ordered probit model also indicate that extension services, risk attitudes, group membership, relational capital, education and labor supply are major determinants of the number of land management practices used. However, financial resources, biophysical factors and some demographic factors are found to have an insignificant effect on sustainable agriculture adoption. This implies that when it is necessary to promote sustainable land management practices and to stimulate smallholder farmers to adopt such practices in isolation or combination, specific strategies should be designed to improve awareness, build positive attitudes, reduce risk aversion, strengthen formal organizations, and empower endogenous groups (or informal institutions).
\end{abstract}

Keywords: social capital; information; risk attitudes; agricultural practices; multivariate analysis.

\section{Introduction}

In most Sub-Saharan African countries, subsistence farming system which is also known as traditional agriculture has remained the dominant farming system. However, this farming system is characterized by very low productivity and weak performance. This is because of land degradation, low use of improved agricultural inputs, limited marketing systems, climate change, and frequent drought [1-3]. 
In Ethiopia, for example, nearly $80 \%$ of the population depends on agriculture to sustain their livelihoods. The sector constitutes about $85 \%$ of the foreign exchange earnings. Furthermore, agriculture has around $43 \%$ share in the gross domestic product [4]. For this reason, agricultural growth not only determines the fate of non-agricultural sectors, but also accelerates overall economic development in the country.

Despite its dominance, the productivity of this sector in these SSA countries remains very low and it has grown by about $2.2 \%$ annually since 1991 . The corresponding figure for developed countries is $3.9 \%$, whereas $4.2 \%$ for other emerging countries. To this end, the low productivity has retarded the growth of other sectors and the overall economy. This demonstrates that the expansion of agricultural productivity gap will continue unless agriculture in less-developed countries especially SSA grows faster than in other countries [5].

As documented in the literature, one way to improve the productivity of the sector is to invest in technologies and implement improved agricultural practices [6]. Agricultural productivity can also be increased through the use of improved varieties and improved farming practices [7-11]. These have the potential to further improve food security, reduce rural poverty, and enhance livelihoods $[7,10,11]$ while maintaining environmental sustainability $[8,9]$.

However, the adoption and diffusion of improved technologies and sustainable agricultural practices in these countries still remain below the expected levels [5,11-15]. Some authors have conducted research to identify the reasons for the low adoptions. According to those studies, the low adoption of sustainable agriculture was associated with factors such as demographic variables, plot-location characteristics, information access, financial resources, government effectiveness, and the presence of shocks, for example, flooding and climate change [12,14-16].

Undoubtedly, even the findings from these studies are highly variable across locations and among regions. Subsequently, a location-based specific study is often necessary to understand the real factors that prevent farmers from adopting productivity-enhancing technologies and agricultural practices. In addition to this, farmers' decisions to adopt technological innovations depend on multiple and interrelated factors [17]. Considering this, additional empirical evidence is therefore still needed to understand what motivates smallholder farmers to adopt technologies and improved agricultural practices [18].

Furthermore, in the traditional adoption literature, the main focus was on how socioeconomic variables and biophysical factors affect technology adoption. However, how socio-psychological issues affecting adoption behavior have received attention in the more recent literature, for example, by the following previous studies [17-22]. Nevertheless, these empirical studies are potentially limited and insufficient to capture or address the effect of socio-psychological factors on (actual) adoption decisions, especially relating to sustainable agriculture.

In this essence, more empirical studies are still needed to adequately understand their impacts on sustainable agriculture adoption. In addition, the potential role of attitudes, social capital, personal competencies, capacity building, and information in the adoption decisions are less researched in the contemporary empirical literature. Therefore, it seems pertinent to undertake a study to provide additional empirical literature and then fill the existing knowledge gaps on the subject matter.

Parallel to this, in areas that are susceptible to soil erosion and land degradation that have resource-poor smallholder farmers, and that have small and fragmented farmlands, a possible way to improve productivity and ensure food self-sufficiency is to focus on sustainable agricultural practices [23-25]. Because more sustainable agricultural practices can be adopted using on-farm and locally available inputs, as well as using the knowledge and skills of the farmers to raise fertility, increase water retention, improve productivity, and ensure ecosystem services [21,26,27].

Despite these potentials of sustainable agricultural practices, adoption remains very low and there are few such empirical studies. Therefore, this study aspires to further explore the issues from a different perspective at a micro level how social and psychological factors influence smallholder farmers to adopt sustainable land management practices. 
This paper, hence, aims to investigate how social and psychological factors-such as social capital, attitudes towards farming practices, information sources, and farmers' risk attitudes-affect smallholder farmers' decisions to the adoption of land management practices. Following this, the study contributes to contemporary literature interface by providing empirical evidence on how these socio-psychological issues affect actual sustainable agriculture adoption.

Therefore, this study extends the current literature on socio-psychological issues and adoption behaviors by clearly addressing this research objective. In addition, this paper provides insight and information that helps governments and development actors how to motivate farmers to adopt sustainable land management practices, which have economic and ecological benefits. Therefore, the results of the study have policy relevance and literature contributions.

\section{Theoretical and Conceptual Frameworks}

\subsection{Sustainable Agricultural Practices Studied}

Agricultural practices are defined as sustainable when they are implemented by locally available resources, based on farm households' knowledge and skills, and when they use less external inputs that are harmful to the environment. Sustainable agriculture is an integrated system of livestock and crop production that is capable of transitioning industrialized agriculture into an environmentally-friendly system while maintaining its productivity and competitiveness $[13,16,27]$.

Preliminary discussions were held with agricultural officials, extension agents, and NGOs working in the areas to identify commonly adopted sustainable agricultural practices. Accordingly, farmers have used different several practices to improve soil fertility, increase water retention, and improve productivity -for example, intercropping, anti-erosion measures like soil bunds, stone walls, terracing, agroforestry systems, use of animal manure, expansion of irrigation, incorporation of crop residuals in the soil, set up of water harvesting schemes, crop rotation, use of organic compost, crop diversification, area enclosure, use of improved seed varieties, zero-grazing, and weed management.

From these commonly adopted agricultural practices in the areas, agroforestry systems, application of compost, and crop rotation with legumes are selected to assess the influence of socio-psychological factors on smallholder farmers' choice of these practices (see Table 1 for the definition of these practices). Farmers were asked a dichotomous question (yes/no) as to whether they have applied these specific practices on their field plots for years. In this paper, 'adopter' refers to a smallholder farmer who has adopted a selected agricultural practice (assigned 1); otherwise, they are referred to as a 'non-adopter' (assigned 0). These selected agricultural practices can be adopted separately or in combination and, hence, there are eight possible adoption choices (see Appendix A).

Table 1. Selected sustainable agricultural practices and their definition from local contexts.

\begin{tabular}{ll}
\hline Practices & Definition and Explanation of These Land Management Practices \\
\hline $\begin{array}{l}\text { Agroforestry } \\
\text { systems }\end{array}$ & $\begin{array}{l}\text { Planting multipurpose trees on private plots, such as forage trees, perennial fruit (apples, oranges), } \\
\text { shrubs, moringa trees, silkworm trees, acacia trees, olive and eucalyptus with crops and/or } \\
\text { livestock in the same management unit }\end{array}$ \\
\hline Crop rotation & $\begin{array}{l}\text { Use of different types of crops one after the other, for example, legume crops (beans, chickpea, } \\
\text { lentils, or peas) following cereals (wheat, barley, or maize) in the same area in sequential seasons }\end{array}$ \\
\hline Compost & $\begin{array}{l}\text { Application of organic materials, such as weeds, farm waste, straw/hay leftovers, dry leaves, ash, } \\
\text { and food wastes as organic fertilizer to increase yields }\end{array}$ \\
\hline
\end{tabular}

As indicated in the literature, agroforestry systems that combine both agriculture and forestry practices create more productive and ecologically healthy land-use systems. In addition to food and livestock forage, agroforestry systems could reduce greenhouse gas emissions by capturing carbon, improve resilience to climate variability and extreme drought conditions, and could also enhance soil fertility, leading to higher yields and income [6,28-30]. 
Several studies have also been conducted on crop rotation with legumes and found that crop rotation helps to replenish nutrients because legumes fix nitrogen in the soils. Using cover crops also prevents soil erosion and mitigates diseases/pests that often occur when a single crop is continuously cropped, improves soil structure and fertility by raising biomass, improves yields, and increases income [31,32]. Farmers have often used legume crops-such as peas, beans, chickpeas, and lentils-following cereal crops, such as wheat, barley, and maize. Therefore, these legumes are involved in the rotations with these cereals.

With regards to compost, farmers in the area have often used organic materials-such as weeds, farm waste, ash, food waste, leaves, and straw / hay leftovers-as inputs for compost. Some studies explain that use of compost improves soil fertility, controls soil erosion, and increases crop yields and this tends to raise the income of compost adopters [33,34].

As can be seen in Appendix A, there are three possibilities: marginal probability (unconditional probability) as a probability of adopting agricultural practice regardless of any pre-requirement; conditional probability is the probability of adopting a specific practice given that other practices have already been adopted; and joint probability is the probability of adopting two or more agricultural practices simultaneously. About $46 \%$ of the farmers had adopted agroforestry systems; the corresponding figure for compost application was 55\% and crop rotation with legumes was 59\%. This suggests that there are also a significant number of farmers in the areas who have not yet adopted these practices.

Additionally, about $9 \%$ of the farmers adopted agroforestry systems only but not crop rotation and compost. The corresponding figure for sole compost is about $11 \%$ and $15 \%$ is for only crop rotation. Considering the conditional probability that shows the interdependence decisions, the proportion of farmers who have adopted agroforestry systems, given that they have already applied crop rotation are $59 \%$. The corresponding figure for compost is about $47 \%$. About $14 \%$ of farmers have adopted all these agricultural practices in combination, while about $10 \%$ have not adopted any of the practices. About $11 \%$ have used agroforestry systems combined with crop rotation. Compost and crop rotation with legumes are used jointly by about $18 \%$ of farmers. Furthermore, about $12 \%$ of farmers have adopted agroforestry systems together with compost. Thus, these land management practices are interdependent and individual or separate decisions to adopt them seem less realistic.

\subsection{Defining Socio-Psychological Variable and Estimating Procedures}

The study has both observed variables in the study dataset (for example, education, landholdings, and household size) and latent or unobserved variables (for instance, attitudes, social capital, risk attitudes, and personal efficacy). These latent variables are constructed from statements that are directly observed in the dataset. Each statement is responded by a five-point Likert item, ranging from completely disagree to completely agree, from more unlikely to more likely and from very low to very high. For example, $1=$ more unlikely, $2=$ unlikely, $3=$ uncertain, $4=$ likely, and $5=$ more likely. The lowest value indicates a negative implication, while the highest value shows a positive implication. However, the opposite (reversal) is also possible solely in the questionnaire to keep the counterbalance and consistency of the response.

In addition, the study has both target and control variables. The former variables have direct links with the topic and objective of the study (see Table 2). The discussions and implications of the paper should be mainly targeted on these variables. On the other hand, the latter variables have no direct links with objectives but they are still important because their exclusions might have direct or indirect implications on the efficacy and validity of the paper in general and target variables in particular. To mention some, for example, biophysical factors, and some demographic variables.

Here exploratory factor analysis with a maximum likelihood extraction method is used to construct our latent variables with a homogeneous structure from multiple statements with a heterogeneous structure in the dataset. Subsequently, the mean approach is applied for computing the value of each latent variable from the observed statements that correspond to the derived latent variable, 
because they have common parts and can be loaded onto a single derived variable. For example, five statements are loaded with personal efficacy (see Section 3.2.) and its value is the average value of these observed statements loaded onto personal efficacy.

Table 2. Definition, description, and explanation of some target variables of the study.

\begin{tabular}{|c|c|}
\hline Variables & Explanation of the Variables \\
\hline Attitude & $\begin{array}{l}\text { The level to which a farmer feels to adopt agricultural practices after understanding and evaluating } \\
\text { their positive and negative consequences. }\end{array}$ \\
\hline $\begin{array}{l}\text { Personal } \\
\text { efficacy }\end{array}$ & $\begin{array}{l}\text { The level in which a farmer evaluates own competencies, skills, knowledge, and capabilities } \\
\text { whether those help him to successfully perform agricultural practices. }\end{array}$ \\
\hline $\begin{array}{l}\text { Perceived } \\
\text { resource }\end{array}$ & $\begin{array}{l}\text { The extent of perception of a farmer on how necessary economic resources and rural facilities } \\
\text { facilitate or impede the adoption of sustainable agricultural practices. }\end{array}$ \\
\hline $\begin{array}{l}\text { Media } \\
\text { influence }\end{array}$ & $\begin{array}{l}\text { The level of influence on a farmer's behavior and decisions from formal mass media, like television, } \\
\text { radio broadcast, mobile phones, newspapers, and magazines. }\end{array}$ \\
\hline $\begin{array}{l}\text { Technical } \\
\text { training }\end{array}$ & $\begin{array}{l}\text { Perception of a farmer on how capacity building schemes, like attending short-term course training, } \\
\text { attending on-farm trials or agricultural field days and participating workshop exposure affects his } \\
\text { decisions and behaviors. }\end{array}$ \\
\hline $\begin{array}{l}\text { Extension } \\
\text { services }\end{array}$ & $\begin{array}{l}\text { The level of how access to agricultural advisory services, such as agricultural experts and } \\
\text { development agents influence a farmer's decisions and behaviors }\end{array}$ \\
\hline $\begin{array}{l}\text { Relational } \\
\text { capital }\end{array}$ & $\begin{array}{l}\text { Perception level on how reference groups or informal institutions (friends, families, neighbors and } \\
\text { endogenous clubs, like Equb and Idir), who are important for the farmer, affect his decision and } \\
\text { behavior (also called interpersonal contact = social pressure). }\end{array}$ \\
\hline $\begin{array}{l}\text { Group } \\
\text { membership }\end{array}$ & $\begin{array}{l}\text { A farmer's feeling on how formal organizations (farmers' associations, saving and credit } \\
\text { associations, resource users' groups, and cooperative societies) influence his behavior and decisions. } \\
\text { This is also sometimes known as group pressure. }\end{array}$ \\
\hline Education & $\begin{array}{l}\text { The educational level of the household head whether or not he/she can read and write from } \\
\text { religious education or formal schools }\end{array}$ \\
\hline Labor supply & $\begin{array}{l}\text { Household size adjusted to adult labor equivalent to capture age difference. It is computed as adult } \\
\text { male or female ( } 15-60 \text { years) is assigned } 1 \text {; elders either males and females (+60 years) are } 0.70 \text {; } \\
\text { children both boys and girls (less than } 15 \text { years) is } 0.50 .\end{array}$ \\
\hline $\begin{array}{l}\text { Farming } \\
\text { experience }\end{array}$ & $\begin{array}{l}\text { The number of years that the household head has stayed in farming. This shows accumulated skills } \\
\text { and knowledge in farming decisions, innovations and other issues }\end{array}$ \\
\hline
\end{tabular}

\subsection{Model Estimation and Explanation}

As explained in the literature, farmers' decisions to adopt technological innovations to improve agricultural productivity and maximize yields are based on their expected utility $\left(U_{i}\right)[11,15]$. Farmers decide to adopt if the expected utility of adopting $\left(U_{i}^{m}\right)$ exceeds the expected utility of not adopting or retaining the traditional management practice $\left(U_{i}^{0}\right)$.

While the expected utility cannot be observable, the adoption decision to the practices can be observable. In this case, we can derive this unobserved utility from the observed variable. Then, smallholder farmers' choice for sustainable land management practices is given as

$$
D_{i m}= \begin{cases}1 & \text { if } D_{i m}^{*}=\mathrm{E}\left(U_{i}^{m}-U_{i}^{0}\right)=\alpha X_{i m}^{\prime}+\varepsilon_{i m} \geq 0 \\ 0 & \text { Otherwise }\end{cases}
$$

Where $D_{i m}$ is the observable variable and $D_{i m}^{*}$ is a latent variable representing the decisions of farmers $(i)$ to adopt land management practices $(m)$. This depends on a vector of explanatory variables, such as attitude towards the practices, social capital, farmers' risk attitudes and demographic factors $\left(X_{i m}^{\prime}\right)$, and unobserved characteristics $\left(\varepsilon_{i m}\right)$. The error terms are expected to capture errors in optimization and perception.

In the presence of more land management practices, farmers can adopt them in combination or separately. If the adoption of these practices is interrelated, a separate estimation may lead to under (over) estimation. Accordingly, a joint analysis is therefore preferable. This retains the potential 
correlation between unobserved disturbances. It also allows for possible contemporaneous correlation in the adoption decision [35].

Following this fact, adoption decisions for interdependent or interrelated land management practices have a multivariate structure. A multivariate probit model is hence more appropriate to handle such issue [35]. Therefore, the multivariate probit function can be specified as

$$
D_{i m}^{*}=\alpha_{i} X_{i m}+\varepsilon_{i m} ; \quad D_{i m}=1\left(D_{i m}^{*}>0\right) \quad \varepsilon \sim \operatorname{MVN}(0, \Omega)
$$

Where the error terms jointly follow a multivariate normal distribution (MVN) with zero means and variance normalized to unity, $\Omega$ refers to a symmetric variance-covariance matrix, $\rho$ is the conditional tetrachoric correlation between two different agricultural practices.

$$
\Omega=\left[\begin{array}{ccc}
1 & \rho_{12} \ldots & \rho_{1 m} \\
\rho_{12} & 1 \ldots & \rho_{2 m} \\
\ldots \ldots & \ldots \ldots \ldots \ldots . . \ldots & \ldots \ldots \\
\rho_{1 m} & \rho_{2 m} \ldots & 1
\end{array}\right]
$$

While this model allows us to estimate the probability of adopting land management practices, it does not define the number of land management practices adopted. In the literature, it is usually assumed that farmers adopting two strategies or practices have higher expected utility levels than farmers adopting only one strategy [36]. This can be expressed mathematically as

$$
U\left[F\left(M_{1 i}, M_{2 i}\right)\right]>U\left[F\left(M_{0 i}, M_{1 i}\right)\right]
$$

To capture this, two models are suggested, namely, the ordered probit model [11-15] and the censored least absolute deviation (CLAD) [36,37] Both could help to explore factors that influence the number of land management practices adopted. In both models, the dependent variable $\left(Y_{i}\right)$ is the number of agricultural practices adopted. Assuming three land management practices, farmers adopt zero $\left(Y_{i}=0\right)$, one $\left(Y_{i}=1\right)$, two $\left(Y_{i}=2\right)$ and three $\left(Y_{i}=3\right)$ practices regardless of their sequences and combinations. While the CLAD model assumes this to be a continuous variable, it is assumed to be an ordered variable by the ordered probit model. In this paper, the ordered probit model is used by assuming it to be an ordered variable.

With regards to the ordered model, at first sight, the number of land management practices adopted seem to be count data, which would justify the use of a Poisson regression model instead of an ordered probit model. However, the events do not have perceived equivalence probabilities for occurrence or adoption. In addition, the dependent variable is assumed by the Poisson model as a continuous variable, whereas it is assumed by this study as an ordered variable.

Furthermore, the probability of adopting the first land management practice is also found to differ from the probability of adopting the second land management practice [11]. The ordered model is appropriate and what is important here is whether the farmer adopts zero, one, two, or more land management practices despite the sequences and combinations. This function is given as

$$
P\left(Y_{i}=j \mid X_{i}\right)=P\left(X_{i} \beta+e_{i} \leq \lambda_{j} \mid X_{i}\right)=\Phi\left(\lambda_{j}-X_{i} \beta\right)-\Phi\left(\lambda_{j-1}-X_{i} \beta\right) ; j=0,1,2,3
$$

where $\Phi($.$) is the standard normal cumulative distribution function, \beta$ is a parameter vector and $\lambda_{0}<\lambda_{1}<\lambda_{2}<\lambda_{3}$ are unknown threshold parameters to be estimated by maximum likelihood. For these facts, both the multivariate probit model and the ordered probit model are expected to produce more reliable results on the factors that affect the adoption of sustainable agriculture. 


\section{Research Methods and Data}

\subsection{Sampling Framework and Survey Design}

This study was conducted in six rural villages in northern Ethiopia, which is located between $13^{\circ} 40^{\prime}$ to $14^{\circ} 0^{\prime}$ north latitude and $39^{\circ} 40^{\prime}$ to $40^{\circ} 0^{\prime}$ east longitude (see Figure 1 ). Of the total catchment area (district), 9\% of the areas are found in the dry temperate zone (1003-1500 m above sea level), $36 \%$ are in the warm temperate $(1500-2300 \mathrm{~m})$, and $55 \%$ is found in the temperate zone $(2300-3069 \mathrm{~m})$. The mean annual temperature is $20^{\circ} \mathrm{C}$ and the mean annual rainfall is nearly $400 \mathrm{~mm}$ with an estimated coefficient of variation of $34 \%$ based on rainfall data over 33 years (1983-2015). Nonetheless, the rainfall is often unpredictable, erratic, and variable. The estimated population is around 144,000 and about $75 \%$ entirely depending on agriculture [38]. The major crops grown in the areas are wheat, barley, broad beans, chickpeas, lentils, and field peas. Livestock—especially small ruminants and apiculture-is an integral part of the farming system.

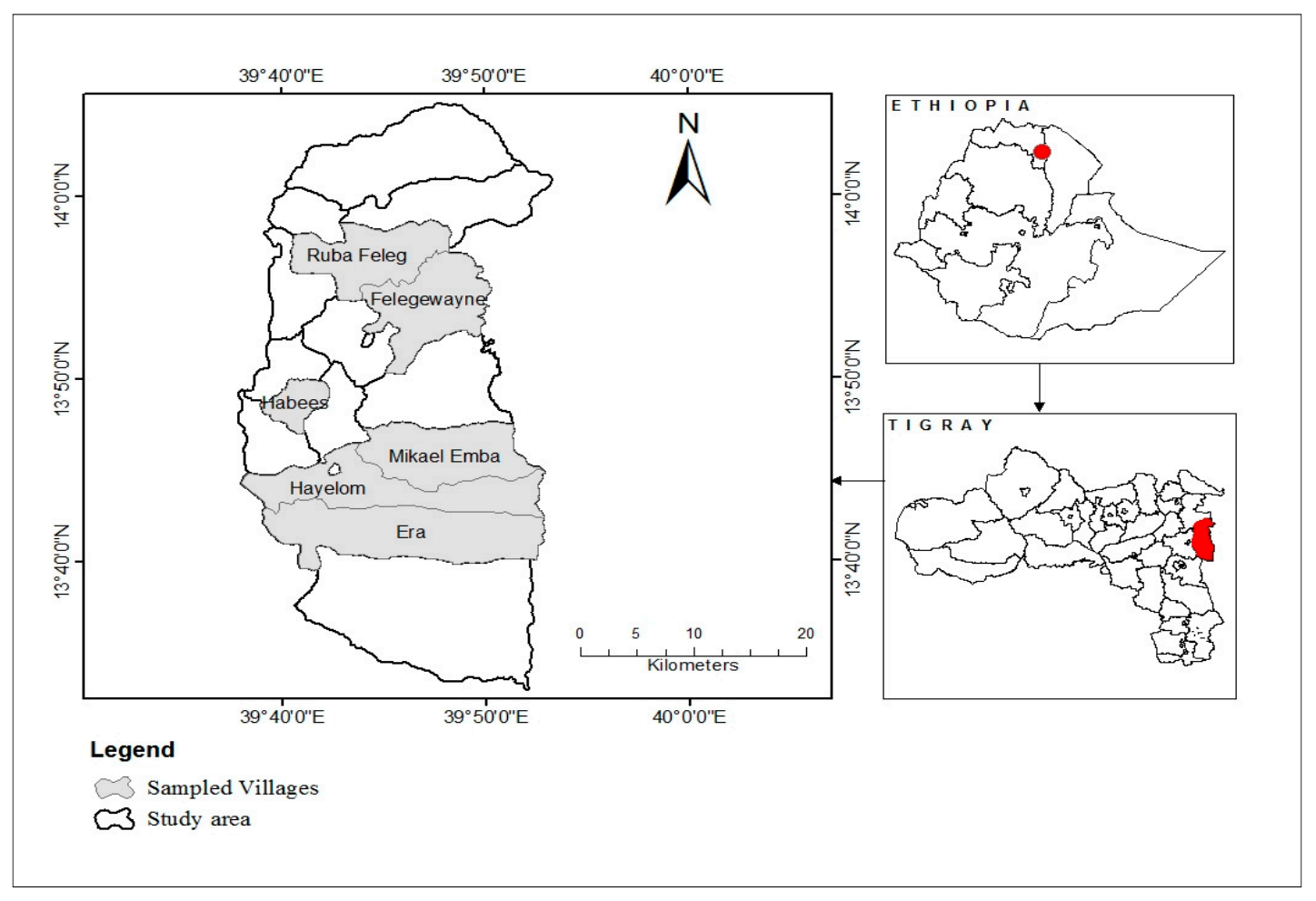

Figure 1. Overview of a map of the study area within Ethiopia, Tigray, and the district.

The study area was purposively selected. It is one of the drought-prone areas in the country. Due to its topographic features (mountains and hills), it is also highly susceptible to soil erosion and land degradation. Besides, traditional continuous farming practices and overgrazing can aggravate this. Furthermore, the area is located very close to the Afar depression, one of the hottest and lowest areas on the earth. As a result, the local people have often been exposed and vulnerable to its adverse climatic effects. In line with these issues, farmers are expected to adopt different sustainable land management practices to reduce the adverse effects of drought, climate change, desertification, and other shocks, as well as to improve agricultural productivity and yields. In the light of these, the study area seems appropriate to undertake this research focusing on decisions and behavior with regard to the adoption of sustainable land management practices.

The study area has 18 administrative villages and these are grouped into two types based on agroecology. 16 villages are located in the temperate zone, and two villages in the warm temperate zone (Eira and Kelisha Emni). Certain parts of some villages are characterized by the dry temperate 
zone but there is no permanent settlement there. Five villages: Felege Weyni, Habes, Hayelom, Michael Emba, and Ruba Feleg from the temperate zone and Eirra village from the warm temperate zone were randomly selected. These selected villages represent around 33\% of the total villages in the catchment area. At the time of the survey, these villages had about 9230 household heads. The required sample size ( $\mathrm{n}=350)$ was determined following the Yamane (1967) formula. After allocated this to each village proportionally, they were selected from the sampling frame of each village using a systematic random sampling method.

The data of this research originated from the cross-sectional survey and collected using a standardized questionnaire. To ensure the reliability of the data, the survey passed through several iterations. Firstly, the questionnaire was drafted following a review of previous adoption studies [39-46] to understand the conceptions of socio-psychological issues and sustainable land management practices. Secondly, the draft was contextualized by some extension agents and development practitioners working in the area to assess the quality and content of these questions. Furthermore, the questionnaire was pretested by ten randomly selected farmers who were not included in the final survey. These pre-assessments have helped to improve the standard and quality of the questionnaires. The final version of the questionnaires contained valuable information on agricultural practices, information sources, attitudes, socio-psychological variables, demographic factors and risks. The household survey was administered by trained and experienced enumerators under the close supervision and follow-up of the research team.

\subsection{Validating and Evaluating Data Qualities}

Most of our target variables are latent and are constructed from statements in the dataset using factor analysis. For example, four statements that show the extent to which the farmer feels to adopt land management practices after understanding their positive and negative consequences are loaded into attitudes. Five different statements that capture the level of learning and influence from various community groups (friends, neighbors and informal groups) who are important for the farmer are loaded into relational capital. Three statements that show the level of impact on decisions that formal organizations, such as farmers' associations, resource users' groups, saving and credit associations and cooperatives are loaded into group membership.

Extension service is measured from three statements that indicate the level of influence of extension agents and how farmers are confidence in the information obtained from them. Perceived resource is derived from three statements that explain whether economic resources and rural facilities affect actual adoption of sustainable land management practices. Moreover, statements relating to the influence of formal media, such as television, radio broadcast, mobile phones and magazines on farmers' decisions and behavior are loaded into the same variable and named media influence. Furthermore, the extent of influence from attending short-term courses and participating in agricultural field days and workshops is loaded into technical training. Finally, five statements that show whether the knowledge and skills of the farmer influence to successfully adopt sustainable land management practices are loaded into personal efficacy.

In the literature, there are several ways to check the reliability, normality, multicollinearity and validity of the data, especially the latent variables $[47,48]$. The convergent validity or accuracy that explains whether observed statements are measuring what they are designed to measure can be checked by the factor loading and variance extracted. Appendix B shows that the coefficients of average factor loadings for these variables (indicates whether the statements can measure the same concept in agreement) and variances extracted (the amount of variance in the statements accounted by for the latent variables) exceed the minimum recommended value (factor loading $\geq 0.60$ and variance extracted $\geq 0.50$ ). As indicated in the variance extracted, the total variance of the statements explained by each latent variable varied between $55 \%$ and $72 \%$. The coefficients of Cronbach alpha $(\alpha)$ that tests reliability (internal consistency or similarity) describes how closely related the statements to measure a single latent is found higher than the recommended level for all the latent variables 
$(\alpha \geq 0.70)$. Thus, these statements that correspond to each derived latent variable have common parts. They are more reliable and valid to explain the latent variables. They, therefore, can adequately be loaded onto a single variable using a mean approach.

The normality assumption is checked by Skewness and its value for each variable does not deviate from the univariate normality assumption. 2-tailed Pearson moment correlation analysis (contingency coefficient) is also used to check multicollinearity between these variables and they are found statistically uncorrelated. Therefore, these variables are fitted for subsequent estimation and standard inference. The mean score for the latent variables lies above three points, pointing to positive implications. For example for attitude, a high value indicates a positive or favorable attitude towards sustainable land management practices. The target and control variables of the study have no serious problems of non-normality and multicollinearity so that they can be used for further inference and exploration. Finally, robust standard errors estimation is used to correct for potential heteroscedasticity problem (if any).

\subsection{Demographic and Socioeconomic Profile of Respondents}

Appendix $C$ presents the summary statistics for some variables. Nearly $82 \%$ of the farmers are living in villages located in the temperate zone, while the remaining are from the warm temperate zone. About $58 \%$ of the samples are male-head households and they have a mean farming experience of 23 years. About $86 \%$ are followers of an Orthodox religion, while the remaining are Muslims, Catholics and Protestants. Agriculture is the main sector that has been serving as a primary source of livelihoods for about $67 \%$ of the farmers, while the others have been engaged largely in petty trade, small businesses, selling of charcoal and firewood and causal works. The mean labor supply which is household size adjusted to adult equivalent is slightly less than four persons.

Coming to the educational level of the household head, about $54 \%$ could not read and write, while about $46 \%$ were literate. About $8 \%$ of the farmers did not have any livestock while the remaining had livestock with a mean of 2.40 TLU (Tropical Livestock Unit determine livestock density and 1 TLU $=1$ camel, 0.7 cows, 0.8 oxen, 0.1 shoats, 0.5 donkey, 0.45 heifer $/$ bull, 0.75 mule/horse, 0.2 bee colonies or 0.01 chickens). Landholding in the area is small and fragmented with a mean landholding size of 0.56ha. The qualities of the farmland vary from flat to steep slopes and from very fertile to infertile soils. While evaluating the plots, on average, about $25 \%$ of the plots are perceived by the farmers to have flat slopes and about $30 \%$ have fertile soils. Around $45 \%$ of the farmers had received credits, while about $18 \%$ did not need any credit because they are wealthy or credit averse. However, $37 \%$ of the farmers had no access to credit due to collateral constraints.

With regard to risk attitudes, farmers were asked a general question 'to what extent are they willing to take risks in the agricultural production, such as natural hazards, personal issues, technology risks, market volatility and financial shocks'. This was responded by a five-point Likert scale, such as very unlikely to take risks (assigned 1), unlikely to take risks, not sure about, prepared to take risks and highly prepared to take risks (assigned 5). About $6 \%$ of the farmers are not ready to take any risk at all while about $16 \%$ are extremely willing to take risks. About $22 \%$ of the farmers are uncertain whether to take or evade risks. About $30 \%$ of the farmers are relatively willing to take risks while about $26 \%$ are not willing to take risks. This farmers' attitude towards risks can be grouped into three: those farmers who are unlikely and extremely unlikely to take risks (risk averse), those who are not sure whether to take or evade risks (neutral) and those who are prepared and very much prepared to take risks (risk seekers). Nearly $46 \%$ of the farmers are risk seekers while about $32 \%$ are risk-averse farmers. The remaining are uncertain either to take or evade the risks, because they want to decide based on objective evidence and specific characteristics rather than on the activity itself. 


\section{Results and Discussion}

\subsection{Factors Influencing Farmers' Adoption of Sustainable Land Management Practices}

This section explores factors that influence farmers' decisions to adopt agroforestry systems, compost fertilizer and crop rotation with legumes. Table 3 presents the results of the multivariate probit model, which is estimated using the maximum likelihood method. The Wald chi-square test indicates that the estimated model is overall significant. The slope coefficients are jointly different from zero. This suggests that the model has a strong explanatory power.

The rho likelihood ratio test shows that the correlation of the error terms across the three different equations is statistically significant. The choices for these selected agricultural practices are interdependent; a positive coefficient for complementary effect and a negative coefficient for substitution effect. For example, compost and crop rotation $(\rho=-0.26)$ are substitutable, while agroforestry systems and compost $(\rho=0.31)$ are complementary. Agroforestry systems and crop rotation are unrelated, because they have no significant correlation. Table 3 shows that education, labor supply, social capital, risk attitudes, farming experience, extension services and attitudes are factors that significantly affect farmers' choice to adopt agroforestry systems, crop rotation with legumes, and compost application.

\subsubsection{Behavioral Factors}

This includes attitudes towards risks (risk attitude) and attitudes towards sustainable agriculture. Farmers' attitudes are constructed from observed statements relating to perceived easiness, perceived usefulness and perceived compatibility of agricultural practices [46,49]. The findings indicate that attitude has a significant and positive effect on adopting crop rotation with legumes and compost application. Farmers who have highly positive attitudes towards both practices are more likely to adopt them. This suggests that they have perceived those practices as useful for them; easy to understand, learn and adopt; and they are compatible with their existing farming values and traditions. However, farmers' attitudes towards agroforestry systems are not linked to their adoption. Therefore, positive attitudes have significant impacts on inspiring farmers to implement some land management practices to improve productivity.

In the literature, similar findings were reported previously. For example, the significant and positive impacts of farmers' attitudes on adopting ecological focus areas and private sustainability schemes [19], using agri-environmental schemes, such as environmental fallow and use of alternative crops in special protected areas [50], implementing pro-environmental agricultural practices [51], converting non-organic agriculture to organic agriculture [52] and adopting various agricultural practices $[13,53]$. Similarly, perceived advantages and perceived compatibility were found to be significant predictors for adopting conservation tillage, grassed waterways, filter strips and cover crops in the US [54].

Concerning risk attitudes, it is stated that the more willing the farmers are to take risks, the higher their risk attitudes, and the less inclined they are to implement any risk-reducing strategy. This suggests that an individual who is more (less) willing to take risk will have a lower (higher) subjective/perception of risks [55]. For this fact, we include farmers' risk attitude in the model as a proxy variable for uncertainty or aversion. Table 3 indicates that risk attitude is negatively related to the probability of adopting compost, whereas it is positively related to the probabilities of adopting agroforestry systems and crop rotation.

The question is to understand the factors that indicate positive effects of risk attitudes on the adoption of agroforestry systems and crop rotation, as well as negative impacts on the application of compost. Assuming that risk seekers have more livestock than risk averse farmers, risk seekers may not prefer compost because they need the organic materials for their livestock, for example, weeds, farm waste and leaves. However, this may not work for risk averse farmers. Risk seekers may also prefer other practices (animal manure, agroforestry systems, and crop rotation) to compost due to the labor and time demands of compost preparation (collecting, mixing and distributing). 
With regards to agroforestry systems, farmers have to purchase the seedlings (permanent fruit, Moringa trees, mulberry or silkworm trees, livestock forage) and these trees also require some time before harvesting. Accordingly, the cost and time implications may lead to risk averse farmers not to use agroforestry systems or use them less. However, this may not work for risk seekers. In addition, shrubs, eucalyptus, acacia trees, olive trees and other trees often compete for land with crops. Due to their small landholdings, risk averse farmers may be less likely to use agroforestry systems, but risk seekers may not care about the size of the land as long as these practices have opportunities for them.

Several authors report that risk-averse farmers are more reluctant to adopt sustainable agricultural practices and therefore have a lower probability of adoption decisions compared to risk seekers. For example, a lower adoption of risk averse farmers for improved technologies [56], pro-environmental land management practices [57], and sustainable agricultural practices until adequate information is available [58]. On the other hand, risk attitude, which measures to what extent a person is willing to take or to avoid risk, was found to have a negative influence on the intended and actual adoption of risk management strategies. Higher risk attitudes mean a greater willingness to take risks and a lower likelihood of implementing risk management strategies [55].

\subsubsection{Social Capital and Information}

In this study, social capital includes both relational capital and group membership, while the source of information includes extension service and mass media. Formal organizations (e.g., farmers' associations, resource users' groups and cooperative societies), and interpersonal interaction and informal communication among local community groups help farmers in the area to exchange information, to harmonize their beliefs and attitudes, and to overcome resource constraints. Table 3 confirms the positive effect of social capital on the adoption of agroforestry systems, grain-legume rotational practices and compost. This constitutes evidence that formal organizations, neighbors, friends and other community groups stimulate smallholder farmers to adopt sustainable land management practices.

Previous studies have documented the positive effect of social capital on adoption. The number of sunflower adopters increased when there were strong social ties among friends and families [59]. Peers and family members shaped the demand for protecting and preserving land and water resources [60]. The positive impacts of agricultural leaders on the adoption of sustainable environmental practices have been documented [51]. A positive impact of social pressure was observed for the adoption of organic agriculture [52]. Membership of farmers' organizations was found to positively affect the adoption of agricultural technologies [1]. Besides, farmers who are adopting some sustainable agricultural practices could influence other farmers around them to adopt different agricultural practices [61].

Apparently, information is an important input in making farming decisions. A decision to use sustainable farming practices was positively shaped by the availability of technical information [60]. Lack of information was also found to hinder the adoption of sustainable practices [62]. Uncertainty (or aversion) is reduced when information is diffused, which motivates the uncertain group to adopt improved technologies [58]. Therefore, access to alternative information sources (mass media and extension services) is included in the model to investigate the potential effects of information on implementing agricultural practices. The probability of farmers adopting them increases if they have access to alternative information. With adequate information on the attributes of agricultural practices, farmers reduce their uncertainties and that enables them to be more willing to adopt land management practices.

In this regard, extension services have a significant and positive effect on the adoption of agroforestry systems and crop rotation with legumes. At village level, there are some agricultural extension agents who are assigned by the government to advise farmers about improved technologies and agricultural practices. They can help them to become aware of their attributes, advantages and disadvantages. Several authors, for example, in Vietnam [13], Tanzania [16], the US [63], Zambia [64], and in Kenya [65] reported that extension agents positively influenced the adoption of improved 
farming practices. Farmers are more likely to adopt improved farming practices if they have frequent contacts with public extension agents. They could encourage them to apply these farming practices.

Some farmers in the area have access to television or radio that helps them to obtain agricultural information, because agricultural issues are sometimes broadcast nationally through these devices. The findings show that the media has a significant positive influence on the implementation of compost but an insignificant effect on the adoption of agroforestry systems and crop rotation with legumes. It seems that the use of compost, including the process of preparing it, is broadcast by the government media agency. In line with this result, it was reported in the literature that the presence of radio or television positively influenced the adoption of insect-resistant corn, drought-tolerant soybean varieties, and conservation practices $[14,63,65]$. Conversely, farmers' access to a mobile phone [14] and radio [66] were found to insignificantly affect the adoption of improved practices.

\subsubsection{Capacity Building and Competence}

This includes technical training, education, farming experience, labor supply and personal efficacy. In almost every rural village in Ethiopia, farmers' training centers have been established and equipped (partially) with the necessary human resources and physical facilities with the aim of transferring knowledge about improved farming practices and technologies. These centers have served as demonstration sites. Capacity building training or demonstrations have often been organized in these centers, esp. by practitioners, to transfer technological innovations and improved farming methods. The centers are also used to store improved inputs, such as chemical fertilizers, improved seeds, pesticides and herbicides so that farmers can obtain these inputs from the centers.

Table 3 illustrates that technical training has a significant positive effect on the adoption of compost, but it does not affect agroforestry systems and crop rotation. This suggests that compost requires practical training and field trials to see how it is prepared and implemented while this is not the case for the other land management practices. Previous studies have confirmed that participation in farm-level demonstrations or capacity building training contributes positively to farmers' decisions to adopt sustainable practices, such as farmyard manure, seeds of improved varieties, crop rotation and green compost $[1,16,65]$.

In personal efficiency essence, the application of conservation practices and integrated soil management techniques requires farmers to learn new skills and knowledge to determine the functioning of the soil and the impact on agricultural yields [11]. Following this, personal efficacy (farmers' knowledge, skill and competence) is included in the model to understand its impacts on adoption decisions. As stated above, five different statements relating to internal qualities of farmers are loaded to personal efficacy and this is the average value of these statements. However, farmers' abilities and competence are removed from the model due to the multicollinearity effect with risk attitudes. While observed in the literature, the perceived ability, which represents farmers' competence and experience, was found to positively influence farmers' intentions and adoption of organic avocado production. Growers who had a negative perception of their abilities were less likely to become involved in organic production [52]. Similarly, a self-concept that includes personal norms and personal competence was also found to positively predict sustainable practices [51].

Apart from this, farming experience, labor supply and education can also reflect competence and cumulative knowledge of farmers. In the literature, previous innovation was found to be a potential predictor in the adoption of ecologically sustainable practices [19], and conservation tillage practice and herbicide-resistant cotton varieties [67]. In this regard, farming experience is used to approximate the previous innovation of farmers and is proposed to have a positive effect on current adoption. The results of the study show that farming experience has a significant positive effect on the adoption of agroforestry systems and a negative effect on compost application. This suggests that farmers with more farming experience are unlikely to adopt compost, i.e., application of compost is negatively correlated with experience. 
This might be linked to age and negative experience. Firstly, preparation of compost is not easy. It is labor intensive and time-consuming to collect the organic materials used for compost from different sources and to prepare the compost itself. Since there is a strong correlation between age and farming experience, these factors might explain a dislike by more experienced farmers for compost. Secondly, the negative past experiences of farmers in the area might be a particular reason. For example, silkworm trees were given to farmers and they planted on their field plots, but no-one (neither the government, researchers nor NGOs) provided them with the insects. Accordingly, they abandoned the silkworm trees from their field plots after four years.

The availability of labor supply is an important determinant of adoption decisions [11,19]. In smallholder systems, household size can be a proxy variable for family labor endowment. The larger the family, the more labor is available not only for agricultural production but also for non-agricultural activities. Therefore, a large family does not suffer from a shortage of labor supply. Here labor supply is found to have a significant positive effect on the adoption of compost, but an insignificant effect on agroforestry systems. This suggests that compost demands more labor, and the probability for using compost is higher for large families. Thus, a large labor supply allows farmers to execute sustainable agriculture, especially labor-intensive land management practices.

The potential effect of education on the adoption of agricultural practices has been seen, because education improves awareness of farmers about technologies and improved practices, and also enables farmers to achieve greater efficiency in farming production [64]. Table 3 shows that literate farmers are more likely to apply agroforestry systems, crop rotation with legumes, and compost to enhance productivity, compared to illiterate farmers. Literate farmers show a greater preference for agroforestry systems and crop rotation but less preference for compost. Therefore, education is important to enhance awareness and promote the adoption of sustainable agricultural practices. In this regard, previous studies have reported mixed findings. On one hand, farmers' education was found to have an insignificant impact on adopting conservation tillage and herbicide-resistant cotton varieties [67]. On another side, it has a significant positive impact on the adoption of insect-resistant corn and soybean varieties [63] and the adoption of a greater number of sustainable agriculture [11,13]. Therefore, education can be positively correlated with the use of sustainable agriculture.

\subsubsection{Other Socioeconomic and Biophysical Factors}

In some previous studies, gender had an undefined effect on adoption $[15,56]$. In this study, the gender of the farmers has a significant positive effect on the adoption of agroforestry systems and compost, but it has an insignificant effect on the adoption of crop rotation. Female-headed households might be less likely to adopt compost owing to time constraints since they are responsible for all household activities. Preparing compost is also not an easy task because it is labor intensive. Accordingly, males may be relatively physically stronger than females to perform these labor-intensive activities. Therefore, the probability of implementing compost as organic fertilizers is higher for male-headed than for female-headed households.

As explained in the literature [46], rural facilities and capital resources either retard or expedite decisions to adopt technological innovations. Accordingly, perceived resources are included to determine how this influences the adoption of sustainable agriculture. Based on factor analysis, three observed statements relating to the impacts of resources and facilities are loaded to perceived resources, and this has a significant positive effect on compost. Farm households can apply compost if economic resources (e.g., organic materials) are not perceived to be obstacles, as well as if there are institutions that provide training in how to prepare and use compost. Additionally, special skills and access to credits, which show financial capacities, have insignificant effects on all these agricultural practices. This may indicate that these practices may not require purchased inputs or may not need institutional support for their implementation.

These results, nevertheless, can be inconsistent with the existing evidence in the literature. Perceived control that shows the influences of economic resources and physical facilities was found to 
be a significant predictor for the adoption of environmental conservation practices [19] and the adoption of land management practices [51]. An individual decision to implement sustainable agricultural practices was also positively shaped by infrastructure and necessary physical resources [60]. In addition, the availability of resources-such as money and access to credits-had a positive influence on the use of seeds of improved varieties, chemical fertilizers, and sustainable agricultural practices $[65,66]$. These show that economic resources and infrastructure facilitates are important facilitators of the adoption of sustainable agricultural practices.

In the area, the livelihood of most farmers relies on mixed farming: both livestock and crops. Farmers with more livestock and large landholdings are more likely to have a higher output and income and to be wealthier. Livestock are sources of food, biogas, manure, and income. Manure can be complementary or substitutable for other practices. As indicated by the results, the physical quantity of livestock (TLU) reduces the application of compost, but it does not affect agroforestry systems and crop rotation. The number of livestock has a significant and negative impact on the adoption of compost. This might be linked to two explanations. Firstly, farmers could prefer and choose other agricultural practices, for example, such as animal manure. Secondly, there may be a competing effect between the organic materials used to produce compost and animal feeds. In Ethiopia, the organic materials used for compost-such as weeds, farm waste, leaves, and food waste-are often given to animals. Consequently, farmers who have animals prefer not to use compost.

However, the results for agroforestry systems differ from observations in the area. Farmers have often collected fodder and forage from exclosure and multipurpose trees. The leaves of various trees, such as acacia trees and other local trees, are used as animal feed. They have collected grasses and forage from the managed and exclosure areas through cut and carry feeding systems. Despite these advantages of agroforestry systems, livestock insignificantly affects agroforestry systems. In previous studies, mixed findings were reported. Livestock did not affect the adoption of crop rotation, inorganic inputs, conservation tillage, and improved seeds [15]. On the other hand, a higher likelihood of adopting agroforestry was reported with a larger number of livestock [29].

Table 3. Coefficients of the explanatory variables: results of the multivariate probit model.

\begin{tabular}{|c|c|c|c|c|c|c|}
\hline \multirow{2}{*}{ Variables } & \multicolumn{2}{|c|}{ Agroforestry } & \multicolumn{2}{|c|}{ Compost } & \multicolumn{2}{|c|}{ Crop Rotation } \\
\hline & Coefficient & Robust std. err. & Coefficient & Robust std. err. & Coefficient & Robust std. err. \\
\hline Education & 0.286 & $0.142 * *$ & 0.276 & $0.143 *$ & 0.077 & 0.044 * \\
\hline Relational capital & 0.111 & $0.046^{* *}$ & 0.102 & 0.087 & 0.192 & $0.087^{* *}$ \\
\hline Group membership & -0.097 & 0.087 & 0.138 & 0.073 * & 0.053 & $0.018^{* * *}$ \\
\hline Technical training & -0.051 & 0.082 & 0.041 & $0.019^{* *}$ & 0.078 & 0.079 \\
\hline Media influence & -0.060 & 0.088 & 0.080 & $0.033^{* *}$ & 0.126 & 0.088 \\
\hline Attitudes & -0.088 & 0.066 & 0.033 & $0.011^{* *}$ & 0.054 & $0.015^{* * *}$ \\
\hline Extension services & -0.199 & $0.102 *$ & 0.055 & 0.097 & 0.071 & $0.022 * * *$ \\
\hline Perceived resources & -0.017 & 0.072 & -0.062 & $0.021^{* *}$ & 0.003 & 0.096 \\
\hline Risk attitudes & 0.307 & $0.114^{* *}$ & -0.035 & $0.012 * *$ & 0.081 & $0.017^{* * *}$ \\
\hline Labor supply & 0.040 & 0.039 & 0.035 & $0.015^{* *}$ & 0.068 & $0.039 *$ \\
\hline Gender (male) & 0.126 & $0.039 * * *$ & 0.102 & $0.051^{* *}$ & -0.095 & 0.148 \\
\hline Experience (log) & 0.141 & $0.045^{* *}$ & -0.016 & $0.009 *$ & 0.127 & 0.129 \\
\hline Livestock & -0.046 & 0.045 & -0.065 & $0.025^{* *}$ & 0.047 & 0.046 \\
\hline \multicolumn{7}{|c|}{$\begin{array}{l}\text { Overall estimated model test: } \\
\text { Wald chi-square test: } \chi^{2}(63)=95.2 ; \mathrm{P}\left(\chi^{2}\right)=0.007 ; \mathrm{n}=350 \\
\text { rho Likelihood ratio test: } \rho_{\text {agroforestry }}=\rho_{\text {rotation }}=\rho_{\text {compost }}=0 ; \chi^{2}(3)=17.3, \mathrm{P}\left(\chi^{2}\right)=0.014\end{array}$} \\
\hline \multicolumn{7}{|c|}{$\begin{array}{l}\text { Estimated covariance of the correlation matrix } \\
\text { rho }_{\text {rotation-compost }}=-0.26(0.043)^{* *} ; \text { rho } \text { agroforestry-compost }=0.31(0.003)^{* * *} ; \text { rho }_{\text {agroforestry-rotation }}=0.07(0.105)\end{array}$} \\
\hline
\end{tabular}

Notes: Others variables: religion, personal efficacy, special skills, farm conditions (size, fertility, and slopes), agroecology, occupation, and credit access Significant level: ${ }^{*},{ }^{* *}$ and ${ }^{* * *}$ shows statistically significant at 10,5 , and $1 \%$, respectively. 


\subsection{Determinants of the Number of Sustainable Land Management Practices Adopted}

As stated above, farmers can adopt these sustainable land management practices individually or in combinations. This section assesses the factors that influence the adoption of the number of (intensity) land management practices regardless of their sequences and combinations. This is estimated by the ordered probit model. The dependent variable is the number of sustainable agricultural practices adopted (none, one, two, and three practices), while socio-psychological factors, demographic characteristics, and biophysical variables are some explanatory variables.

Table 4 presents the determining factors for the aggregate number of sustainable land management practices adopted. The results of the coefficients of the ordered probit model reveal that education, labor supply, social capital, attitudes, risk attitudes, extension services, technical training, and perceived resources have significant effects on the number of sustainable agricultural practices adopted. However, demographic variables (farming experience, gender, and religion), landholding size, credit access, special skills, agroecology, and possession of a radio or television are not associated with the number of sustainable land management practices used.

Membership in formal organizations and relationships with local community groups (social capital) have positive spillover for smallholder farmers to adopt more and various sustainable agricultural practices. As outlined in Table 4, the marginal effect of the ordered probit model indicates that farmers who have strong ties, relationships, and networks within local community groups -such as neighbors, families, friends, and relatives-are 5-6\% more likely to apply one or more agricultural practices than other farmers. Farmers who are members of formal organizations (and understand their strong influence), such as farmers' associations and cooperative societies, have a $6 \%$ higher probability of adopting two or more sustainable land management practices. This suggests that rural institutions and interpersonal communications and relationships are important factors for smallholder farmers to motivate them to adopt a combination of land management practices.

While assessing farmers' attitudes towards sustainable agriculture, it is found to have a positive impact on the adoption of more agricultural practices. For example, adoption of two or more land management practices increases by about $10 \%$ with an increase in the value of attitudes towards five points (strongly agree), while adopting either nothing or solely one practice (regardless of which practice) declines by $7-11 \%$ if the attitude is positive or increases to five points. This suggests that positive attitudes of farmers towards sustainable agriculture can lead to the adoption of more sustainable land management practices.

Concerning extension services and technical training, they have mixed effects. As indicated in Table 4, extension services negatively influence farmers to adopt solely one land management practices but positively affects them to apply a combination of these land management practices. Similarly, the unexpected result of technical training is the insignificant effect for the adoption of solely one sustainable land management practices (regardless of which practices), even if technical training inspires farmers to adopt a combination of land management practices. Practically, extension agents in the area have taught or advised farm households to adopt more agricultural practices to improve productivity. Receiving participatory (or experimental) capacity building training has been shown to stimulate farmers to apply more land management practices to enhance productivity.

As indicated in the ordered model (Table 4), risk attitude is positively correlated with the adoption of a combination of sustainable land management practices, but negatively related to the adoption of solely one practice. This suggests that, because of the uncertainty issues, farmers who are risk averse (who have a lower value of risk attitudes) are less likely to adopt a combination of sustainable land management practices. They do not want to take risks. On the other hand, risk seeker farmers (who have a higher value of risk attitudes) are more likely to adopt more and a combination of land management practices. This suggests that risk seekers can adopt more land management practices as long as these practices have opportunities.

In essence to education, literate farmers are more likely to adopt a number of land management practices than illiterate farmers. This might be linked to awareness of the attributes and benefits of 
sustainable agriculture. This suggests that literate farmers could benefit from the positive effects of education. With regard to labor supply, large families positively contribute to the adoption of more land management practices in combination. This is for the fact that many land management practices are labor intensive. Table 4 also indicates that farming experience, however, does not influence whether or not farmers have to adopt more land management practices to enhance productivity.

As indicated by Table 4, both the coefficient and marginal effects of the ordered probit model indicate that livestock ownership also tends to impede farmers from adopting more land management practices. This suggests that livestock ownership does not encourage farmers to adopt a number of sustainable agricultural practices. For every additional livestock unit, the probability of adopting two and more land management practices is reduced from 1 to $4 \%$. This suggests that there is a negative relationship between livestock husbandry and some practices of sustainable agriculture due to the following explanations.

Firstly, it seems that they can compete for time, resources, and labor. For example, production of leftovers (crop residues) has been often used for livestock feed. The organic materials used for compost have been also used as livestock feed. Secondly, sustainable agriculture -such as completely managed, rotational grazing systems, and planting multipurpose trees-does not encourage free grazing of meadows and communal areas and therefore compels farmers to reduce their size of livestock. As a result, most farmers could not favor this. They, rather, prefer free grazing even if they understand that free grazing feeding system is not sustainable and effective.

With regards to farmland conditions, occupation, and slopes and fertility of farmland are found to be significant variables, while the remaining variables are not associated with the number of sustainable farming practices used. The availability of economic resources and physical facilities does not help farmers to adopt more practices. Agroecology is included to capture spatial effect across locations (villages) and agro-climatological zones because different areas may have different characteristics that make farmers to more prone to adopt (or not adopt) particular agricultural practices. However, it was found insignificant, maybe due to small area coverage of the study.

The aim of implementing sustainable land management practices—such as agroforestry systems, organic fertilizers, and bio-diversification-is to reduce soil erosion and land degradation, as well as to improve the quality or fertility of farmlands, which leads to improving productivity. Following this, farmlands that have flat slopes and fertile soils are less likely and demanded to execute sustainable practices compare to steep slopes and unfertile soils. Therefore, farmers who have cultivated lands with flat slopes and fertile soils are unlikely to be motivated to adopt more agricultural practices.

In short, with the exception of some variables, the ordered probit and multivariate probit models reported very similar results for the probability of adopting sustainable land management practices. Also, the target variables (sociopsychological factors) — such as attitude, perceived resources, personal efficacy, relational capital, group membership, risk attitudes, information, education, and labor supply-are found to have joint significant effects on the probability and intensity (number) of adopting these land management practices. However, not all these variables are statistically significant from an individual perspective.

Therefore, social and psychological issues are vital to stimulating smallholder farmers to adopt sustainable agriculture that has economic and ecological benefits. Specific risk-averting strategies are needed to reduce uncertainty and build local resilient systems, and to motivate farmers to focus on quality livestock, for example, providing insurance schemes, arranging credits, giving livestock management training, providing timely information, and organizing various capacity building initiatives to enhance awareness.

It is important to rethink the importance of inter-personal relationships and communications, technical assistance and formal organizations in building confidence, bringing changes in mindset, and stimulating farmers to adopt more sustainable land management practices. Local people who live in particular areas with adjoining land have not only the same behaviors, attitudes, and norms but 
also shared similar interest and they have common problems. As a result, these could help them to develop strong beliefs, attachment, and trust in collective actions and decisions. interest

In this situation, if there are some farmers who can be considered as a successful example in the villages, especially in adopting sustainable agricultural practices, neighbors and other farmers can go and observe the benefits of these practices. These model farmers can convince other farmers to adopt those agricultural practices at minimum efforts than that of the government bodies. Also, trained and dedicated extension agents can convince farmers in the demonstration sites that sustainable agricultural practices are compatible with their existing traditions, are adaptive to their local environment and have positive impacts on agricultural productivity.

Table 4. Coefficients and marginal effects of explanatory variables: the ordered logit model.

\begin{tabular}{|c|c|c|c|c|c|}
\hline \multirow{2}{*}{$\begin{array}{l}\text { Explanatory } \\
\text { Variables }\end{array}$} & \multirow{2}{*}{$\begin{array}{c}\text { Coefficient of } \\
\text { Parameters }\end{array}$} & \multicolumn{4}{|c|}{ Marginal Effects of Parameters } \\
\hline & & $P(Y=0 \mid X)$ & $P(Y=1 \mid X)$ & $P(Y=2 \mid X)$ & $P(Y=3 \mid X)$ \\
\hline Education & $0.47(0.21)^{* *}$ & $-0.05^{* *}$ & $-0.07^{* *}$ & $0.06^{* *}$ & $0.06^{* *}$ \\
\hline Labor supply & $0.04(0.02)^{* *}$ & $-0.04^{* *}$ & -0.01 & $0.05 *$ & $0.05^{* *}$ \\
\hline Relational capital & $0.04(0.02) * *$ & 0.04 & $0.06^{* * *}$ & $0.05^{* * *}$ & $0.05^{* *}$ \\
\hline Group membership & $0.22(0.12) *$ & $-0.07^{* *}$ & $0.04 *$ & $0.06^{* * *}$ & $0.06^{* *}$ \\
\hline Technical training & $0.04(0.12)$ & 0.03 & -0.01 & $0.05^{* * *}$ & $0.05^{* * *}$ \\
\hline Media influence & $0.09(0.12)$ & -0.01 & -0.01 & 0.03 & 0.03 \\
\hline Attitude & $0.08(0.03)^{* *}$ & $-0.07^{* * *}$ & $-0.11^{* * *}$ & $0.10 * *$ & $0.10 * *$ \\
\hline Extension services & $-0.09(0.05) *$ & 0.01 & $-0.01 *$ & 0.03 & $0.03^{* *}$ \\
\hline Risk attitude & $0.34(0.17)^{* *}$ & $-0.03^{* *}$ & $-0.05 *$ & $0.05^{* *}$ & $0.05^{* *}$ \\
\hline Perceived resources & $-0.03(0.04)$ & 0.01 & -0.03 & -0.02 & -0.02 \\
\hline Occupation & $-0.57(0.22)^{* *}$ & $-0.05^{* *}$ & $-0.09 * *$ & $0.06^{* *}$ & $0.06^{* *}$ \\
\hline Livestock & $-0.02(0.03)$ & -0.02 & 0.01 & $-0.06^{*}$ & $-0.07^{* *}$ \\
\hline Flat slopes & $-0.57(0.23)^{* *}$ & $0.05 * *$ & $0.08^{* *}$ & $-0.06^{* *}$ & $-0.06^{* *}$ \\
\hline Fertile soils & $-0.62(0.26)^{* *}$ & $0.06^{* *}$ & $0.09 * *$ & $-0.07^{* *}$ & $-0.07 *$ \\
\hline \multicolumn{6}{|c|}{ Observed and predicted probabilities } \\
\hline & & $Y_{i}=0$ & $\mathrm{Y}_{\mathrm{i}}=1$ & $Y_{i}=2$ & $Y_{i}=3$ \\
\hline \multirow{2}{*}{\multicolumn{2}{|c|}{$\begin{array}{l}\text { Observed } \\
\text { Predicted }\end{array}$}} & 0.12 & 0.31 & 0.41 & 0.16 \\
\hline & & 0.10 & 0.30 & 0.40 & 0.16 \\
\hline
\end{tabular}

Overall ordered logit model diagnosis:

Wald chi-square test: $2(21)=41 ; \mathrm{P}(2)=0.006 ;$ Pseudo R2 = 0.45; $\mathrm{n}=350$

Notes: Other variables: religion, gender, experience, agroecology, personal efficacy, farm size, credit access;

$*, * *$, and ${ }^{* * *}$ represents statistically significant level at 10,5 , and $1 \%$, respectively; figure in the parenthesis are robust standard error for respective variables.

\section{Conclusions and Implications}

This article explores how attitudes, social capital, personal efficacy, information, and risk attitudes influence smallholder farmers' decisions for a simultaneous adoption of sustainable land management practices. In the area under consideration, many smallholder farmers have introduced and implemented land management practices, such as agroforestry systems, compost, and crop rotation to enhance productivity. However, there are still a significant number of smallholder farmers who had not yet adopted these practices. The results of the multivariate probit model (adoption probability) illustrate that information, social capital, attitude towards sustainable agriculture, education, and risk attitudes are significant factors determining adoption of these sustainable land management practices.

Viz., adoption of agroforestry systems is affected by education, risk attitudes, social capital, extension services and attitudes. Similarly, social capital, risk attitudes, technical training, attitudes, perceived resources, education, labor supply, and livestock influence the use of compost. Furthermore, the major factors that affect the use of crop rotation to raise productivity include risk attitudes, media influence, social capital, extension services, attitudes, education, and labor supply. The ordered probit 
model generates major determinant factors that affect the number of sustainable land management practices adopted (intensity), for example, extension services, risk attitudes, group membership, relational capital, education, labor supply, and farmland conditions.

This suggests that social capital, education, attitudes, and perceived resource have positive impacts to implement more than one sustainable land management practices. There are also some factors that uniformly influence the adoption and intensity of sustainable land management practices. Socio-psychological variables that were undermined in the conventional or traditional literature while have been received attention in the recent contemporary literature foster the adoption of multiple sustainable land management practices. Therefore, it is possible and feasible to improve soil fertility, conserve the natural resource base, enhance water retention capacities, and increase agricultural yields through the promotion of the adoption of sustainable land management practices.

This study is expected to have some shortcomings that need to be acknowledged. Firstly, it does not consider the time path of adopting these practices so it lacks dynamic effects. The focus of the study was also at farm level but not at plot level because it was difficult to undertake this in the small and highly fragmented plots. For example, the mean plots are four plots with a mean distance from home to plots of $30 \mathrm{~min}$. Moreover, there is suspicion of and endogeneity problem, especially extension services and group memberships. Farmers are more likely to adopt if they are advised by and have frequent contact with extension agents. On the other side, without encouragement of the extension agents, farmers can adopt and later go to farmers' training centers or contact extension agents for technical help. People who already adopted these practices are also more likely to come together to discuss farm-related issues. Finally, due to the small area coverages, the results of this study are not assumed to universally applied and extrapolated automatically to the entire country.

Despite these reservations, the main findings are still highly relevant and useful for the sampled villages and other villages in Ethiopia with similar agroecology, farming practices, and socio-cultural practices. In addition, since sustainable land management practices are often interrelated, these results can be transferred to other agricultural practices, such as anti-erosion measures. Furthermore, we think that the possibility of endogeneity bias does not reduce the validity of the results because the target variables are latent and constructed from observed statements, which are less vulnerable to the endogeneity problem. The reversal direction (from adoption to the extension services and group memberships) has not been observed practically in the area under consideration. Other studies have used both variables in adoption models and do not find endogeneity problem $[10,14,16,64]$.

Therefore, governments, researchers, academicians, NGOs, and other development actors should strengthen and empower formal and informal institutions, and create strong interrelational networks among local community groups to use their potentials positively. They should also capacitate the competence of extension agents and organize various awareness enhancing initiatives to reduce aversion behaviors. These economic actors should improve understanding of farmers and inspire them to adopt sustainable land management practices, especially in dryland and water stressed areas. In general, enhancing awareness, providing timely information, and organizing capacity building that enable individuals to uptake more sustainable agricultural practices, and that make reduce individuals risk aversion.

Finally, we suggest the following point for further investigation: time effect on adoption decisions of sustainable land management practices-what factors encourage adoption of these practices over time-and the cascade effect of adopting agricultural practices, because a farmer who adopted one practice was six times more likely to adopt other practices [68]. Moreover, the impact of plot-variability that captures a distance from home to each plot should further be investigated. Furthermore, whether extension services and group membership-especially in less developed countries-have an endogeneity problem in the adoption model should be addressed. Finally, in reality, the adoption of technologies highly varies across locations but it is found here insignificant. Therefore, the spatial effect (location variability) on the adoption of sustainable agricultural practices should be known and understood 
by research studies that cover a wider geographical area with a larger sample size across different agro-ecological conditions.

Author Contributions: Conceptualization, W.Z. and S.S.; Methodology, W.Z. and S.S.; carried out the empirical studies and the literature review, W.Z.; Software, W.Z.; Formal Analysis, W.Z.; Data Curation, W.Z.; Writing-Original Draft Preparation, W.Z.; Writing-Review \& Editing, S.S.; Supervision, G.T., G.V.H., H.A., S.S.; Project Administration, G.V.H.; Funding Acquisition, W.Z., S.S.

Funding: The cost of this research was funded by Ghent University through BOF scholarship, Mekelle University, Research and Capacity Building in Climate Smart Agriculture in the Horn NORAD-NORHED, and Open Society Foundations-Africa Climate Change Adaptation Initiative (ACCAI).

Acknowledgments: The authors would like to extend our sincerest thanks for editors and anonymous reviewers for the valuable suggestions and comments provided. We are also grateful for the farmers who shared their time and provided us valuable information.

Conflicts of Interest: The authors declare no conflict of interest. The funders have been acknowledged. However, they had no role in the design of the study; in the collection, analyses and interpretation of data; in the writing of the manuscript; and in the decision to publish the results.

\section{Appendix A}

Table A1. Conditional and unconditional probability of adopting agricultural practices.

\begin{tabular}{ccccc}
\hline \multirow{2}{*}{ Conditions } & \multirow{2}{*}{ Agricultural Practices } & \multicolumn{2}{c}{ Percentage of Farmers Who Adopted } \\
\cline { 3 - 5 } & & Agroforestry Systems & Crop Rotation & Compost \\
\hline Independence & Unconditional probability & 46 & 59 & 55 \\
probabilities & Only specific practice & 9 & 15 & 11 \\
\hline \multirow{2}{*}{ Joint probabilities } & Crop rotation & 11 & 0 & 18 \\
& Compost & 12 & 18 & 0 \\
\hline \multirow{2}{*}{ Conditional } & Agroforestry systems & 100 & 61 & 60 \\
probability & Crop rotation & 59 & 100 & 57 \\
& Compost & 47 & 56 & 100 \\
\hline
\end{tabular}

\section{Appendix B}

Table A2. Summary statistics of major latent variables with reliability, validity and normality.

\begin{tabular}{ccccccccc}
\hline Latent Variables & $\begin{array}{c}\text { Observed } \\
\text { Statement }\end{array}$ & Mean & $\begin{array}{c}\text { Standard } \\
\text { Deviation }\end{array}$ & $\begin{array}{c}\text { Cronbach } \\
\text { Alpha }\end{array}$ & $\begin{array}{c}\text { Factor } \\
\text { Loading }\end{array}$ & $\begin{array}{c}\text { Variance } \\
\text { Extracted }\end{array}$ & Skewness \\
\hline Attitudes & 4 & 3.46 & 1.06 & 0.83 & 0.79 & 0.67 & -0.32 \\
Extension services & 3 & 3.22 & 1.03 & 0.71 & 0.76 & 0.59 & 0.35 & -0.07 \\
Media influence & 3 & 2.67 & 0.83 & 0.74 & 0.75 & 0.57 & -0.19 \\
Relational capital & 5 & 3.55 & 0.82 & 0.81 & 0.75 & 0.66 & -0.14 \\
Technical training & 4 & 3.35 & 0.91 & 0.81 & 0.78 & 0.68 & 0.72 & 0.27 \\
Group membership & 3 & 3.78 & 0.82 & 0.73 & 0.80 & 0.62 & 0.13 \\
Personal efficacy & 5 & 3.38 & 0.57 & 0.82 & 0.77 & 0.62 & -0.05 \\
Perceived resources & 3 & 3.21 & 0.75 & 0.78 & 0.74 & 0.62 & &
\end{tabular}




\section{Appendix C}

Table A3. Definition and explanation of some variables and their respective (mean/share).

\begin{tabular}{|c|c|c|}
\hline Variables & Mean & Description and explanation of the variables \\
\hline Gender (male) & 0.58 & Sex of the household head ( 1 for males and 0 for females) \\
\hline Age & 48.0 & Age of the household head in the time of survey (years) \\
\hline Religion & 0.86 & 1 if the farmer adheres to Orthodox Christian beliefs and 0 for others \\
\hline Occupation & 0.67 & 1 for the farmer whose primary source of livelihood is agriculture \\
\hline Experience & 23.0 & Number of years that the farmer has been experienced in farming (years) \\
\hline Family size & 4.30 & Number of persons living together with the head (household size) \\
\hline Labor supply & 3.90 & Number of persons living in the household adjusted to adult equivalent \\
\hline Education & 0.46 & 1 if the farmer can read and write otherwise 0 \\
\hline Livestock & 2.41 & Total livestock resource per household head (TLU) \\
\hline Farm size & 0.56 & Total landholding size of the household head (hectare) \\
\hline Flat slopes & 0.42 & 1 if the farmer has perceived his land to have flat slopes and 0 if not \\
\hline Fertile soils & 0.30 & 1 if the farmer has perceived his land as fertile, otherwise 0 \\
\hline Agroecology & 0.82 & 1 if the farmer is from a village located in the temperate zone and 0 if not \\
\hline Credit & 0.45 & 1 if the farmer wants and obtains credits, otherwise 0 \\
\hline Risk attitude & 3.43 & $\begin{array}{l}\text { Attitude of farmers towards risks relating to financial shocks, market volatility, } \\
\text { natural hazards, personal issues, technology risks }\end{array}$ \\
\hline
\end{tabular}

\section{References}

1. Bonabana-Wabbi, J.; Mogoka, H.; Semalulu, O.; Kirinya, J.; Mugonola, B. Adoption of integrated soil fertility management by groundnut farmers in Eastern Uganda. J. Dev. Agric. Econ. 2016, 8, 86-94.

2. Todaro, M.P.; Smith, S.C. The developed and developing world. In Economic Development, 11th ed.; Prentice Hall: Upper Saddle River, NJ, USA, 2011.

3. Norton, G.; Alwang, J.; Masters, W. Economics of Agricultural Development: World Food Systems and Resource Use, 2nd ed.; Routledge Taylor and Francis Group: London, UK, 2010.

4. National Plan Commission. The 2017 Voluntary National Reviews on SDGs of Ethiopia: Government Commitments, National Ownership and PerformanceTrends; National Plan Commission: Addis Ababa, Ethiopia, 2017.

5. The United Nations Conference on Trade and Development (UNCTAD). The Least Developed Countries Report 2015: Transforming Rural Economies; United Nations Publication: Geneva, Switzerland, 2015.

6. Hillbur, S. Farmer's Perceptions of Agroforestry-A Case Study About the Obstacles and Opportunities for Agroforestry Adoption in Babati, Tanzania; Environment and Development; Södertörn University: Flemingsberg, Sweden, 2014.

7. Muzari, W.; Gatsi, W.; Muvhunzi, S. The Impacts of technology adoption on smallholder agricultural productivity in Sub-Saharan Africa: A review. J. Sustain. Dev. 2012, 5, 69-77. [CrossRef]

8. Lichtfouse, E. Sustainable Agriculture Reviews 11; Springer: Dijon, France, 2012.

9. Veisi, H.; Toulabi, S.B. Factors influencing pro-environmental behaviour in agriculture. In Proceedings of the International Conference on Ecological, Environmental and Biological Sciences, Dubai, United Arab Emirates, 7-8 January 2012; pp. 346-349.

10. Khonje, M.; Manda, J.; Alene, A.D.; Kassie, M. Analysis of adoption and impacts of improved maize varieties in Eastern Zambia. World Dev. 2015, 66, 695-706. [CrossRef]

11. Wollni, M.; Lee, D.R.; Thies, J.E. Conservation agriculture, organic marketing, and collective action in the Honduran hillsides. Agric. Econ. 2010, 41, 373-384. [CrossRef]

12. International Fund for Agricultural Development (IFAD); World Food Programme's (WFP); Food and Agriculture Organization (FAO). The State of Food Insecurity in the World: Meeting the 2015 International Hunger Targets: Taking Stock of Uneven Progress; FAO: Roma, Italy, 2015.

13. Van Thanh, N.; Yapwattanaphun, C. Banana farmers' adoption of sustainable agriculture practices in the vietnam uplands: The case of Quang Tri Province. Agric. Agric. Sci. Procedia 2015, 5, 67-74. [CrossRef]

14. Gumataw, A.; Bijman, J.; Pascucci, S.; Omta, O. Adoption of improved potato varieties in Ethiopia: The role of agricultural knowledge and innovation system and smallholder farmers' quality assessment. Agric. Syst. 2013, 122, 22-32. 
15. Teklewold, H.; Kassie, M.; Shiferaw, B. Adoption of multiple sustainable agricultural practices in rural Ethiopia. J. Agric. Econ. 2013, 64, 597-623. [CrossRef]

16. Kassie, M.; Jaleta, M.; Shiferaw, B.; Mmbando, F.; Mekuria, M. Adoption of interrelated sustainable agricultural practices in smallholder systems: Evidence from rural Tanzania. Technol. Forecast. Soc. Chang. 2013, 80, 525-540. [CrossRef]

17. Swanepoel, C.M.; van der Laan, M.; Weepener, H.L.; Preez, C.C.d.; Annandale, J.G. Review and meta-analysis of organic matter in cultivated soils in Southern Africa. Nutr. Cycl. Agroecosyst. 2016, 104, 107-123. [CrossRef]

18. Yazdanpanah, M.; Hayati, D.; Hochrainer-Stigler, S.; Zamani, G.H. Understanding farmers' intention and behavior regarding water conservation in the Middle-East and North Africa: A case study in Iran. J. Environ. Manag. 2014, 135, 63-72. [CrossRef] [PubMed]

19. Menozzi, D.; Fioravenzi, M.; Donati, M. Farmer's motivation to adopt sustainable agricultural practices. Bio Based Appl. Econ. 2015, 4, 125-147.

20. Wauters, E.; Mathijs, E. The adoption of farm level soil conservation practices in developed countries: A meta-analytic review. Int. J. Agric. Resour. Gov. Ecol. 2014, 10, 78-102. [CrossRef]

21. Foley, K.M. Examining the Voluntary Adoption of Agricultural Conservation Practices in Northern Malheur Country, Oregon. Master's Thesis, Oregon State University, Corvallis, OR, USA, 2013.

22. Martínez-García, C.G.; Dorward, P.; Rehman, T. Factors influencing adoption of improved grassland management by small-scale dairy farmers in central Mexico and the implications for future research on smallholder adoption in developing countries. Livest. Sci. 2013, 152, 228-238. [CrossRef]

23. Hoffmann, U. Assuring food security in developing countries under the challenges of climate change: Key trade and development issues of a fundamental transformation of agriculture. In Proceedings of the EADI General Conference 2011: Rethinking Development in an Age of Scarcity and Uncertainty: New values, Voices and Alliances for Increased Resilience, New York, NY, USA, 26 September 2011.

24. United Nations. Transforming Our World: The 2030 Agenda for Sustainable Development; A/RES/70/1, Seventieth Session, Agenda Items 15 and 116; United Nations: New York, NY, USA, 2015.

25. Abdulai, A.; Huffman, W. The adoption and impact of soil and water conservation technology: An endogenous switching regression application. Land Econ. 2014, 90, 26-43. [CrossRef]

26. Abubakar, M.S.; Attanda, M.L. The Concept of Sustainable Agriculture: Challenges and Prospects. IOP Conf. Ser. Mater. Sci. Eng. 2013, 53, 012001. [CrossRef]

27. Wezel, A.; Casagrande, M.; Celette, F.; Vian, J.F.; Ferrer, A.; Peigné, J. Agroecological practices for sustainable agriculture. A review. Agron. Sustain. Dev. 2014, 34, 1-20. [CrossRef]

28. Mbow, C.; Smith, P.; Skole, D.; Duguma, L.; Bustamante, M. Achieving mitigation and adaptation to climate change through sustainable agroforestry practices in Africa. Curr. Opin. Environ. Sustain. 2014, 6, 8-14. [CrossRef]

29. Zerihun, M.F.; Muchie, M.; Worku, Z. Determinants of agroforestry technology adoption in Eastern Cape Province, South Africa. Dev. Stud. Res. 2014, 1, 382-394. [CrossRef]

30. Sirrine, D. Agroforestry, Soils, and Food Security in Southern Malawi: Interdisciplinary On-Farm Research Linking Sustainability and Livelihoods; University of California: Santa Cruz, CA, USA, 2008.

31. Gan, Y.; Hamel, C.; O'Donovan, J.T. Diversifying crop rotations with pulses enhances system productivity. Sci. Rep. 2015, 5, 14625. [CrossRef] [PubMed]

32. Martin-Rueda, I.; Muñoz-Guerra, L.M.; Yunta, F.; Esteban, E.; Tenorio, J.L.; Lucena, J.J. Tillage and crop rotation effects on barley yield and soil nutrients on a Calciortidic Haploxeralf. Soil Tillage Res. 2007, 92, 1-9. [CrossRef]

33. Ibrahim, M.; Hassan, A.U.; Iqbal, M.; Valeem, E.E. Response of wheat growth and yield to various levels of compost and organic manure. Pak. J. Bot. 2008, 40, 2135-2141.

34. Ouédraogo, E.; Mando, A.; Zombré, N.P. Use of compost to improve soil properties and crop productivity under low input agricultural system in West Africa. Agric. Ecosyst. Environ. 2001, 84, 259-266. [CrossRef]

35. Greene, W. Econometric Analysis, 5th ed.; Pearson Education, Inc.: Upper Saddle River, NJ, USA, 2003.

36. Ali, A.; Erenstein, O. Assessing farmer use of climate change adaptation practices and impacts on food security and poverty in Pakistan. Clim. Risk Manag. 2017, 16, 183-194. [CrossRef]

37. Huang, J.; Ma, S.; Xie, H. Least absolute deviations estimation for the accelerated failure time model. Stat. Sin. 2007, 17, 1533-1548. 
38. Misgina, N.A.; Kebede, F.; Abereha, E.; Abeba, A. Effect of Potassium on tuber yield and yield component of potato (Solanium tubersum) on loamy soils of Atsbi-Wenberta. J. Biol. Agric. Healthc. 2016, 6, 49-56.

39. Bishu, K.G. Risk Management and the Potential of Cattle Insurance in Tigray, Northern Ethiopia. Ph.D. Thesis, Cork University College, National University of Ireland, Cork, Ireland, 2014.

40. Drollette, S.A. Understanding Agricultural Risk; AG/ECON/2009-01RM; Department of Applied Economics Utah State University: Logan, UT, USA, 2009.

41. Legesse, B.; Drake, L. Determinants of smallholder farmers' perceptions of risk in the Eastern Highlands of Ethiopia. J. Risk Res. 2005, 8, 383-416. [CrossRef]

42. Venkatesh, V.; Thong, J.Y.L.; Xu, X. Consumer acceptance and use of information technology: Extending the unified theory of acceptance and use of technology. MIS Q. 2012, 36, 157-178.

43. Lewandowski, M. Risk Attitudes and Measures of Value for Risky Lotteries. Ph.D. Thesis, The European University, Florence, Italy, 2010.

44. Wauters, E. The Use of Social Psychology for Improving the Adoption of Conservation Practices Soil Conservation in Belgium. Ph.D. Thesis, Faculty of Bioscience Engineering KU Leuven, Leuven, Belgium, 2010.

45. Weber, E.U.; Blais, A.-R.; Betz, N.E. A domain-specific risk-attitude scale: Measuring risk perceptions and risk behaviors. J. Behav. Decis. Mak. 2002, 15, 263-290. [CrossRef]

46. Taylor, S.; Todd, P. Decomposition and crossover effects in the theory of planned behavior: A study of consumer adoption intentions. Int. J. Res. Mark. 1995, 12, 137-155. [CrossRef]

47. Kline, R.B. Principles and Practice of Structural Equation Modeling, 3rd ed.; The Guilford Press: New York, NY, USA, 2011.

48. Schumacker, R.E.; Lomax, R.G. A Beginner's Guide to Structural Equation Modeling, 3rd ed.; Routledge Taylor and Francis Group: New York, NY, USA, 2010.

49. Zeweld, W.; van Huylenbroeck, G.; Tesfay, G.; Speelman, S. Smallholder farmers' behavioural intentions towards sustainable agricultural practices. J. Environ. Manag. 2017, 187, 71-81. [CrossRef] [PubMed]

50. Barreiro-Hurlé, J.; Espinosa-Goded, M.; Dupraz, P. Does intensity of change matter? Factors affecting adoption of agri-environmental schemes in Spain. In Proceedings of the 107 th EAAE Seminar-Modelling of Agricultural and Rural Development Policies, Seville, Spain, 29 January-1 February 2008.

51. Price, J.C.; Leviston, Z. Predicting pro-environmental agricultural practices: The social, psychological and contextual influences on land management. J. Rural Stud. 2014, 34, 65-78. [CrossRef]

52. Hattam, C. Adopting organic agriculture: An investigation using the theory of planned behaviour. In Proceedings of the International Association of Agricultural Economics Conference, Gold Coast, Australia, 12-18 August 2006.

53. Hall, T.J.; Dennis, J.H.; Lopez, R.G.; Marshall, M.I. Factors affecting growers' willingness to adopt sustainable floriculture practices. HortScience 2009, 44, 1346-1351.

54. Reimer, A.P.; Weinkauf, D.K.; Prokopy, L.S. The influence of perceptions of practice characteristics: An examination of agricultural best management practice adoption in two Indiana watersheds. J. Rural Stud. 2012, 28, 118-128. [CrossRef]

55. Van Winsen, F. Rethinking Farmers' Intended Risk Behaviour: The Role of Risk Perception, Risk Attitude and Decision Context. Ph.D. Thesis, Ghent University, Ghent, Belgium, 2014.

56. Yu, X.; Hailu, G.; Cao, J. Risk attitudes, social interactions and the adoption of genotyping in dairy production. In Proceedings of the Agricultural and Applied Economics Association's 2014 AAEA/EAAE/CAES Joint Symposium 'Social Networks, Social Media and the Economics of Food, Montreal, QC, Canada, 28-30 May 2014; pp. 1-30.

57. Ghadim, A.K.A.; Pannell, D.J.; Burton, M.P. Risk, uncertainty, and learning in adoption of a crop innovation. Agric. Econ. 2005, 33, 1-9. [CrossRef]

58. Liu, E.M. Time to change what to sow: Risk preferences and technology adoption decisions of cotton farmers in China. Rev. Econ. Stat. 2013, 95, 1386-1403. [CrossRef]

59. Bandiera, O.; Rasul, I. Social networks and technology adoption in northern Mozambique. Econ. J. 2006, 116, 869-902. [CrossRef]

60. Fazio, R.; Baide, J.M.R.; Molnar, J.J. Barriers to the Adoption of Sustainable Agricultural Practices: Department of Agricultural Economics and Rural Sociology; Auburn University: Auburn, AL, USA, 2014.

61. Organisation for Economic Co-operation and Development (OECD). OECD Workshop on the Adoption of Technologies for Sustainable Farming Systems: Wageningen Workshop Proceedings; OECD: Paris, France, 2001. 
62. Tutkun, A.; Lehmann, B.; Schmidt, P. Explaining the conversion to organic farming of farmers of the Obwalden Canton, Switzerland-Extension of the theory of planned behavior within a structural equation modeling approach. In Proceedings of the 80th Annual Conference of the Agricultural Economics Society, Paris, France, 30-31 March 2006.

63. Barham, B.L.; Chavas, J.P.; Fitz, D.; Salas, V.R.; Schechter, L. The roles of risk and ambiguity in technology adoption. J. Econ. Behav. Organ. 2014, 97, 204-218. [CrossRef]

64. Manda, J.; Alene, A.D.; Gardebroek, C.; Kassie, M.; Tembo, G. Adoption and Impacts of Sustainable Agricultural Practices on Maize Yields and Incomes: Evidence from Rural Zambia. J. Agric. Econ. 2016, 67, 130-153. [CrossRef]

65. Okuthe, I.K. The influence of institutional factors on the adoption of integrated natural resource management technologies by small scale farmers in South Western Kenya. Asian J. Agric. Sci. 2014, 6, 16-32. [CrossRef]

66. Ngombe, J.; Kalinda, T.; Tembo, G.; Kuntashula, E. Econometric analysis of the factors that affect adoption of conservation farming practices by smallholder farmers in Zambia. J. Sustain. Dev. 2014, 7, 124-138. [CrossRef]

67. Banerjee, S.; Martin, S.W.; Roberts, R.K.; Larson, J.A.; Hogan, R.J., Jr.; Johnson, J.L.; Paxton, K.W.; Reeves, J.M. Adoption of conservation-tillage practices and herbicide-resistant seed in cotton production. AgBioForum 2009, 12, 258-268.

68. Arellanes, P.; Lee, D.R. The determinants of adoption of sustainable agriculture technologies: Evidence from the hillsides of Honduras. In Proceedings of the 2003 Annual Meeting, Durban, South Africa, 16-22 August 2003; pp. 693-699.

(C) 2018 by the authors. Licensee MDPI, Basel, Switzerland. This article is an open access article distributed under the terms and conditions of the Creative Commons Attribution (CC BY) license (http://creativecommons.org/licenses/by/4.0/). 